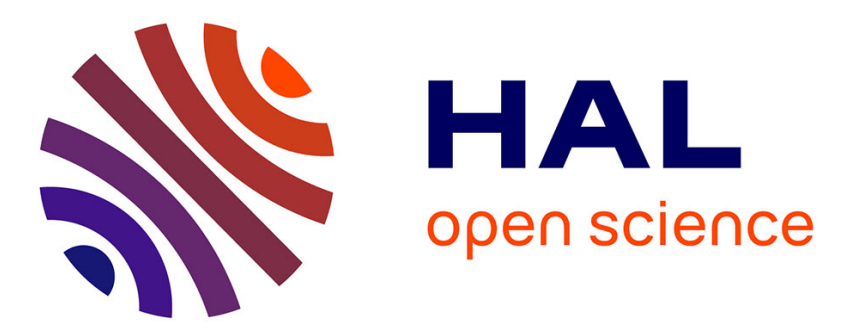

\title{
Experimental characterization of multi-component absorption in complex liquid: New method and apparatus
}

David Benizri, Nicolas Dietrich, Gilles Hébrard

\section{- To cite this version:}

David Benizri, Nicolas Dietrich, Gilles Hébrard. Experimental characterization of multi-component absorption in complex liquid: New method and apparatus. Chemical Engineering Science, 2017, 170, pp.116-121. 10.1016/j.ces.2017.03.024 . hal-01606833

\section{HAL Id: hal-01606833 \\ https://hal.science/hal-01606833}

Submitted on 9 Jul 2021

HAL is a multi-disciplinary open access archive for the deposit and dissemination of scientific research documents, whether they are published or not. The documents may come from teaching and research institutions in France or abroad, or from public or private research centers.
L'archive ouverte pluridisciplinaire HAL, est destinée au dépôt et à la diffusion de documents scientifiques de niveau recherche, publiés ou non, émanant des établissements d'enseignement et de recherche français ou étrangers, des laboratoires publics ou privés. 


\title{
Experimental characterization of multi-component absorption in complex liquid: new method and apparatus
}

\author{
Benizri David $^{\mathrm{a}, *}$, Dietrich Nicolas ${ }^{\mathrm{a}}$, Hébrard Gilles $^{\mathrm{a}}$ \\ ${ }^{a}$ Université de Toulouse; INSA, UPS, INP, LISBP,135 Av. de Rangueil, F-31077 Toulouse, \\ France INRA UMR792, Ingénierie des Systèmes Biologiques et des Procédés, F-31400 \\ Toulouse, France CNRS UMR 5504, Ingénierie des Systèmes Biologiques et des Procédés, F- \\ 31400 Toulouse, France
}

\begin{abstract}
Equilibrium of composition in gas/liquid phases is well known in the simple case of Henry's law. Henry's constants of dissolution describe the water capacity of absorption for one component at pressure ranged from 0 to 10 bars and temperatures from $273 \mathrm{~K}$ to $300 \mathrm{~K}$. However, the experimental determination of the behavior of multicomponents gas in presence of a complex fluid remains a key point in the process industry and research field. An adapted review shows that a simple and robust experimental method is missing to characterize the equilibrium of fugacity between gas and liquid phases. After considering that, authors of this work focus on the main parameters necessarily considered in such case and present an experimental set-up built in that aim. To illustrate the experiments possible with the described apparatus, results are presented for binary gas/liquid operation of equilibrium between a gas mix of $\mathrm{CO}_{2} / \mathrm{CH}_{4}$ and water.
\end{abstract}

Keywords: Multi-component Absorption, Experimental Set-up, Carbon Dioxide, Methane, Henry Constant 


\section{Introduction}

The experimental characterization of fugacity equilibrium between a gas and a liquid phase in complex gas/liquid system is a major issue in process sciences. It can be useful to validate thermodynamic modeling, but it also brings answers for process design in case of a lack of reliable models. The design of absorption and desorption processes in water requires a good knowledge of Henry's constants [1]. Assuming that and in order to design process with water, chemical and process engineers use values that are commonly available ([2], [3]). Thus, engineers often choose to consider that non-polar molecules, light hydrocarbon and Volatile Organic Compounds (VOC) do not dissolve. However, when pressure is relatively high, such phenomenon should be considered. When the gas phase contains more than one gas dissolving in the liquid phase, the model of fugacity equilibrium between gas and liquid phases should be validated before designing the process. This experimental validation must be done in real conditions of operation (pressure, temperature and water quality) of the process. We can conclude that a simple method to determinate Henry's constant could have a large field of application in environmental industry and renewable energies development.

This work aims to set-up and to validate a new apparatus which is able to control and to measure fugacity equilibrium between a gas and a liquid phase. A recent study [4] focused on the determination of Henry's law constants for light hydrocarbon gases at low temperatures ( $274 \mathrm{~K}$ to $293 \mathrm{~K}$ ) and under pressure until 2 bars. They built an experimental process to measure i-butane dissolution. They reviewed data in literature for other gas such as methane. It is important to mention they concluded on the results dependency to temperature for i-butane and pressure for methane. As in this experiments pressure is relatively low, we expect more accuracy with a process that can reach higher pressures. We can now consider the system used in experiments. It is made of a cooled chamber containing a determined volume of pure hydrocarbon gas (ibutane for example). The exact molar concentration in the gas phase is determined with SRK equation of state because of its reliability [5]. Water is then injected with a 
high pressure syringe, and stirred magnetically. The pressure was measured during water injection and stirring to follow gas dissolution. Pressure stabilized and a mass balance was done thanks to the pressure variation as the gas phase was considered invariant in concentration (it is a pure gas). This protocol is suitable as there is no contact between water and gas during the compression of the gas (water is injected after) so that molar concentration before absorption is perfectly known. Here they considered that pressure is the only variable of the system because gas phase concentration did not evolve. It allows authors of the study to do a molar balance on the gas phase. However, this system is not adapted to characterize dissolution of a gas mix because we will need to determinate the gas phase concentration after equilibrium. With this system, such measurement was impossible as interface between water and gas was kept after equilibrium. It led to desorption when proceeding to the determination of the gas phase residue.

On the other hand, balances could be done in liquid phases.

Another work [6] have reviewed experimental techniques to characterize phase equilibrium for the design of gas washing systems. One of these systems aims to measure a solvent saturation in presence of gas mix under high pressures. The set-up was particularly complicated as it realized a saturation of solvent with a re-circulating gas. Gas samples could be taken during circulation, and pressure was controlled. Both phase were analyzed by a gas chromatograph resulting in very accurate analysis. Despite this, they did not explained how gas phase was processed during the absorption phase. It seems that pressure is maintained, however authors of that work did not described how this was realized as the experimental cell is closed. They could inject nitrogen during experiments, but they did not show how and why.

Now that we realized a review on experimental techniques of determination of Henry constant present in literature, it appears that a simple technique which allows determining gas mix dissolution in solvents under pressure is not yet available and that we can propose our experimental set up.

Considering all precedents works, we can deduce that several important factors. 
Agitation is a key point for the transfer to reach the equilibrium. Water (or solvent) quantity must be known. Global volume (gas and liquid) must not change to avoid non desired pressure modifications. Pressure and temperature are the most important parameters. We must be able to measure concentrations in gas phase and in liquid phase before experiments and after experiments. When determining the parameters cited, we must ensure that they are exactly representing a reached equilibrium.

Knowing all those criteria, an experimental set-upa has been built. This process called SATUROMETRIX is a batch contactor of gas and liquid, that is able to separate phase before and after equilibrium in medium pressure conditions (from 1 to $10 \mathrm{bar}$ ). Temperature, pressure and phase concentration of interesting components are valued continuously or sequentially. This study presents the design background and the method of exploitation of the results obtained with such experimental set-up. Some values are presented for the system $\mathrm{H}_{2} \mathrm{O}, \mathrm{CO}_{2}, \mathrm{CH}_{4}$.

\section{Experimental set-up and design}

For the sake of reproducibility, this process is very simple to build. It is made of simple materials. It presents several advantages compared to the precedent state of art.

\subsection{Material}

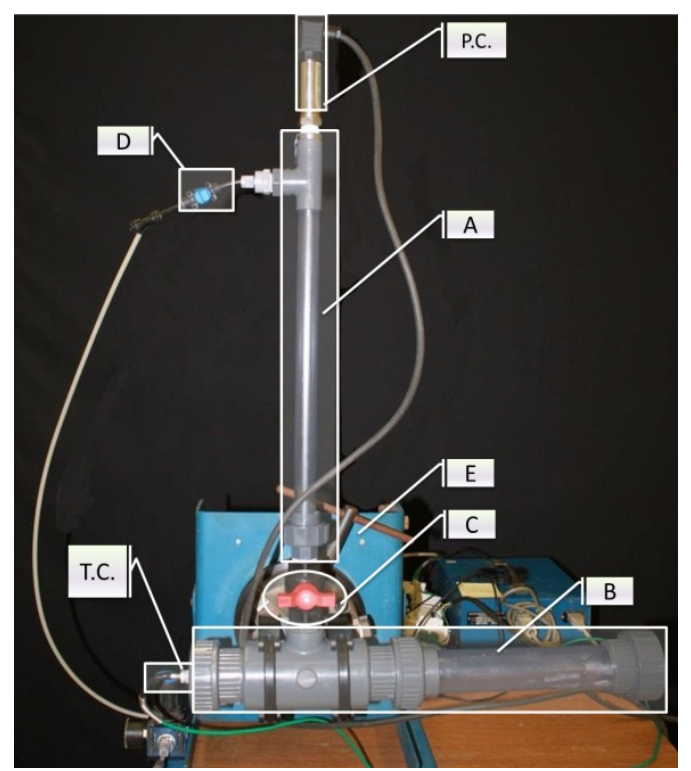

Figure 1 : Experimental set-up of SATUROMETRIX

In figure 1 is presented the experimental set-up built to achieve the gas and liquid 
equilibrium with parameters measurements. P.C. and T.C. mean pressure and temperature controllers. The system is made with two PVC tubes of nominal diameters of 25 and $50 \mathrm{~mm}$ assembled as a Tee, respectively considered as a gas cell (A) and as a liquid cell (B). When assembled, a manual ball valve (C) ensures a segregation of both cells. Those cells can be separated one from another in order to fill the liquid cell with the solvent phase through the ball valve. After having connected both PVC cells as a Tee, gas injection is done by the upper gas valve (D), thanks to a $6 \mathrm{~mm}$ diameter tube. Some remarks have to be taken into account to conduct the experiments successfully. The solvent cell must be completely full and no residual bubbles might stays in it. Air volume previously contained in the gas cell has to be extracted or evacuated before gas injection. The whole system is then insulated (all valves closed) and rotates thanks to a normal axis connected to a rotating motor (E). When the central ball valve is opened, this rotation ensures a mixing of phases that gives a significant interface area. It allows reaching more rapidly the equilibrium between phases

\subsection{Equilibrium control: Pressure, temperature and gas phase analysis}

- Pressure measurements :

Pressure is measured by an Endress et Hauser sensor (Cerabar TP31) show ing $0.3 \%$ full scale error which means $3 \mathrm{kPa}$. Pressure value is transferred to a computer thanks to a Crouzet millenium 3 automate using a sandwich extension and an Ethernet connection to a computer.

- Temperature measurements :

Temperatures $(\mathrm{K})$ of solvent and environment are registered continuously thanks to a type $\mathrm{K}$ mechanical sensor connected to the YCT 4 channel data-logger, loading all data to a computer.

- Gas treatment for analysis :

Gas is recovered at the gas outlet (D in figure 1) thanks to a Tedlar ${ }^{\circledR}$ sampling gas bag of $3.8 \mathrm{~L}$. It is then pumped with a volumetric pump rotating at $100 \mathrm{rpm} / \mathrm{min}$ ensuring a flow at least of $0.3 \mathrm{~L} / \mathrm{min}$. The flow is controlled by a ball flowmeter and water vapor is eliminated from gas using a Peltier cooler (Herrmann Moritz) and a 0.2 micrometer 
filter from Sartorius. Gas flow and pressure are controlled before drying and analysis to ensure the best quality of samples as possible.

- Infrared (IR) gas analysis :

Nowadays, infrared analyzers are a cheaper but robust alternative to gas chromatography measurements, as it shows $1 \%$ of full scale error for each sensor. The infrared analyzer used in this study is the X-stream X2GC (Emerson Process) which realize $\mathrm{CO}_{2}$ and $\mathrm{CH}_{4}$ concentration measurements (\% of the total vol).

2.3. Material and experimental accuracy

Table 1 presents the accuracy of the material presented above.

\begin{tabular}{|l|l|l|l|}
\hline \multicolumn{1}{|c|}{ Equipment } & Range of use & Accuracy & \multicolumn{1}{c|}{ Unit } \\
\hline Pressure & $0-10$ & 0.03 & bar (relative) \\
Temperature & $233-926.5$ & 1.5 & $\mathrm{~K}$ \\
$\mathrm{CO}_{2} / \mathrm{CH}_{4}$ composition & $10-100$ & 1 & $\%$ \\
Gas cell volume & 0.184 & 0.01 & $\mathrm{~L}$ \\
Liquid cell volume & 0.464 & 0.01 & $\mathrm{~L}$ \\
\hline
\end{tabular}

Table 1 : Material involved in the experimental set-up - Range of use and accuracies.

The calculus method of propagation of errors was following the document of reference "Guide to the expression of uncertainty in measurements". An open source software "GUM MC" have been used to characterize the accuracy of the obtained Henry's constant taking into account all errors of measurements and equations.

\section{Equilibrium experiments and calculus}

\subsection{Analysis of pressure variation during experiments}




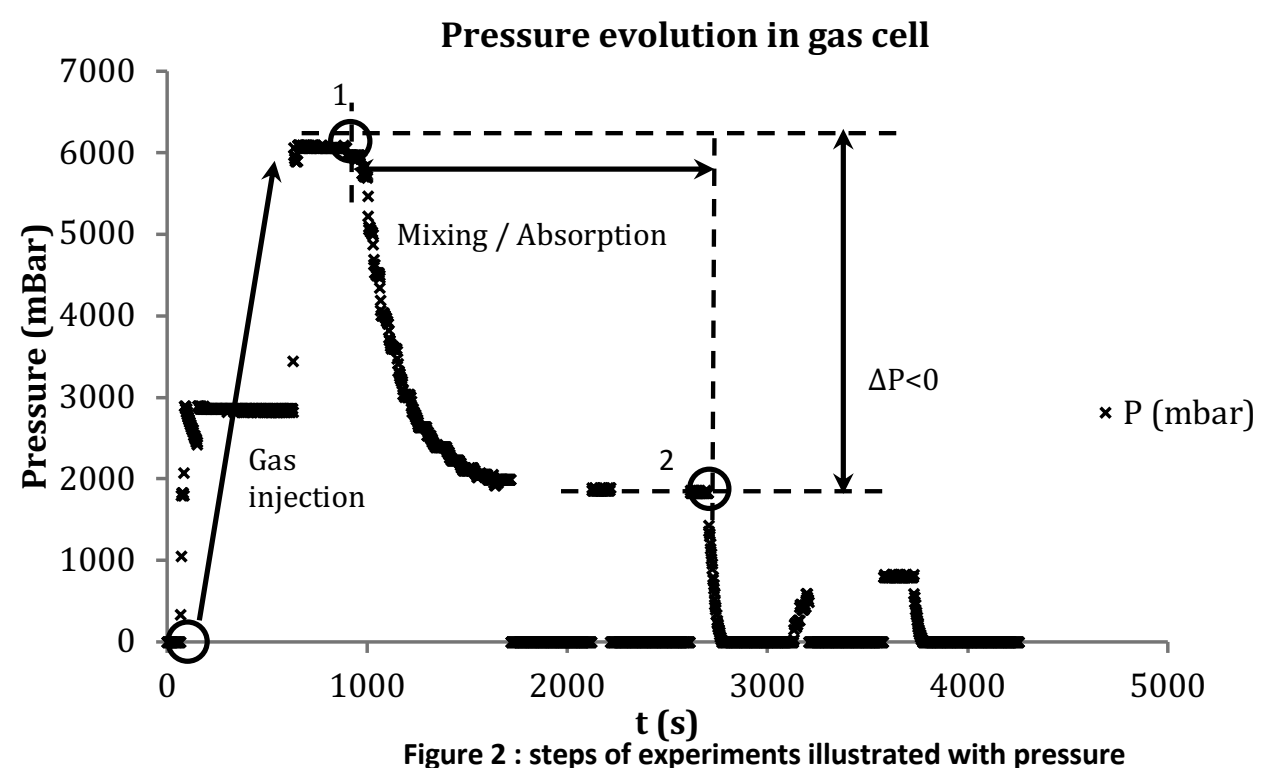

Figure 2 is an illustration of the steps obtained by a continuous pressure measurement in gas cell. The method applied in this work is a gas mass balance between final step 2 and the initial step 1. During absorption, experiment is conducted during a sufficiently long mixing and contacting time to reach equilibrium. $\mathrm{y}_{\mathrm{i}, 1}, \mathrm{P}_{1}, \mathrm{~T}_{1}, \mathrm{y}_{\mathrm{i}, 2}, \mathrm{P}_{2}$ and $\mathrm{T}_{2}$ are measured.

Before measuring the gas concentration at the step 2, we shall segregate the solvent from the gas phase by closing the ball valve after ensuring that no water remains in the gas phase. This ensure that no water desorption would false results.

\subsection{Constant measurement}

After this contact period between phases, a quantity of gas i (for example $\mathrm{CO}_{2}$ or $\mathrm{CH}_{4}$ ) have transferred into water. The first step (1) is the initial gas composition at initial pressure, the step 2 is the final step after absorption. Equation 1 gives the transferred molarity by calculating the gas molar balance, with $\mathrm{Z}_{\mathrm{i}}$ the compressibility factor of the mix of gas at the state $\mathrm{i}$ and $\mathrm{R}$ the perfect gas constant $\mathrm{R}=8.314$.

$$
\frac{P_{1} \cdot \mathrm{y}_{1, i} \cdot V_{\text {tube }}}{Z_{1} \cdot R \cdot T_{1}}=\frac{P_{2} \cdot y_{2, i} \cdot V_{\text {tube }}}{\mathrm{Z}_{2} \cdot R \cdot T_{2}}+n_{\text {trans }, i}
$$

Equation 1 
Then a henry's constant $H_{i}$ can be deduced with equation 2, taking into account the liquid content in the liquid cell and considering that gas composition, pressure and temperature at step 2 are equilibrium parameters.

$$
H_{i}=\frac{P_{2} \cdot y_{2, i}}{\mathrm{Z}_{2} \cdot n_{\text {trans }, i}} \cdot \frac{\rho_{L} \cdot V_{L}}{M_{L}}
$$

Equation 2

\section{Experimental results}

Saturometrix experimental set-up was used and the method applied to determine dissolution constants in the special case of biogas (typically $45 \% \mathrm{CO}_{2} / 55 \% \mathrm{CO}_{2}$ ) absorption in water. For the sake of a process design, three kind of water have been used. A purified water, a tap water and a desorbed water originating from a $\mathrm{CO}_{2}$ absorption column using water as solvent were tested.

Biogas have specific compressibility factors in the range of pressure studied which are detailed in table 2 .

\begin{tabular}{lcc}
\hline Composition & P (bar) & $\mathbf{Z}$ \\
\hline $\mathbf{1 0 0} \% \mathbf{C O}_{2}$ & 7 & 0.957 \\
& 4 & 0.976 \\
& 2 & 0.988 \\
$\mathbf{5 0 \%} \mathbf{C O}_{2} / \mathbf{5 0 \%} \mathbf{C H}_{4}$ & 7 & 0.972 \\
& 2 & 0.992 \\
\hline
\end{tabular}

Table 2 : Compressibility factor $\mathrm{Z}$ at different pressure and gas mix (PROSIM $\left.{ }^{\circledR}\right)$

As this factor is nearly equal to 1 in all cases, perfect gas equation of state $(Z=1)$ has been used for the calculus of matter balance described equation 1 .

\subsection{Results obtained with biogas and pure water}

Table 3 indicates the temperature and pressure at step 1 and 2 for one experiment. It illustrates datas obtained with the experimental set up.

\begin{tabular}{lllll}
\hline Parameter & $\mathbf{P}_{\text {tot }}$ (bars) & $\mathbf{T}_{\mathbf{L}}\left({ }^{\circ} \mathbf{C}\right)$ & $\mathbf{y c o}_{2}$ & $\mathbf{Y c H}_{4}$ \\
\hline Initial (step 1) & 8.104 & 19 & 0.422 & 0.556 \\
Final (step 2) & 5.434 & 19 & 0.192 & 0.75 \\
\hline \multicolumn{4}{r}{ Table 3 : Calculus parameters obtained during the first experiment }
\end{tabular}

Four experiments have been conducted. Results of Henry's constant characterization for $\mathrm{CO}_{2}$ and $\mathrm{CH}_{4}$ are presented in table 4 . 


\begin{tabular}{cccccc}
\hline Exp. & Compound & $\mathbf{T}(\mathbf{K})$ & $\begin{array}{c}\text { Partial } \\
\text { pressure (bars) }\end{array}$ & $\begin{array}{c}\text { Henry's } \\
\text { constant }\end{array}$ & $\begin{array}{c}\text { Experimental } \\
\text { error }\end{array}$ \\
\hline $\mathbf{1}$ & $\mathrm{CO}_{2}$ & 292.15 & 1.045 & $\mathbf{1 4 7 . 9}$ & $4.83 \%$ \\
$\mathbf{2}$ & $\mathrm{CO}_{2}$ & 292.15 & 1.639 & $\mathbf{1 2 8 . 0 6}$ & $3.83 \%$ \\
$\mathbf{3}$ & $\mathrm{CO}_{2}$ & 292.15 & 2.320 & $\mathbf{1 4 5 . 6 8}$ & $3.39 \%$ \\
$\mathbf{4}$ & $\mathrm{CO}_{2}$ & 292.15 & 2.734 & $\mathbf{1 4 8 . 2 7}$ & $3.09 \%$ \\
$\mathbf{2}$ & $\mathrm{CH}_{4}$ & 292.15 & 4.199 & $\mathbf{1 4 9 4}$ & $9.68 \%$ \\
$\mathbf{3}$ & $\mathrm{CH}_{4}$ & 292.15 & 4.429 & $\mathbf{1 5 4 2}$ & $13.20 \%$ \\
$\mathbf{4}$ & $\mathrm{CH}_{4}$ & 292.15 & 4.661 & $\mathbf{1 5 4 9}$ & $12.90 \%$ \\
\hline \multicolumn{6}{c}{ Table 4 : Henry's constant obtained with biogas and pure water }
\end{tabular}

Results for carbon dioxide have an attached experimental error below $5 \%$. Methane Henry's constant is less accurate because methane is less soluble. Carbon dioxide is ten times more soluble than methane in pure water.

4.2. Results obtained with biogas and tap water

The second campaign of experiments was conducted with tap water destined to the $\mathrm{CO}_{2}$ absorption process. Experimental Henry's constants are presented in table 5.

\begin{tabular}{cccccc}
\hline Exp. & Compound & $\mathbf{T}(\mathbf{K})$ & $\begin{array}{c}\text { Partial pressure } \\
\text { (bars) }\end{array}$ & $\begin{array}{c}\text { Henry's } \\
\text { constant }\end{array}$ & $\begin{array}{c}\text { Experimental } \\
\text { error }\end{array}$ \\
\hline $\mathbf{5}$ & $\mathrm{CO}_{2}$ & 292.45 & 1.068 & $\mathbf{1 4 8 . 9 5}$ & $4.90 \%$ \\
$\mathbf{6}$ & $\mathrm{CO}_{2}$ & 292.45 & 1.904 & $\mathbf{1 5 0 . 5 1}$ & $3.80 \%$ \\
$\mathbf{7}$ & $\mathrm{CO}_{2}$ & 292.45 & 2.531 & $\mathbf{1 5 1 . 6 9}$ & $3.33 \%$ \\
$\mathbf{8}$ & $\mathrm{CO}_{2}$ & 292.45 & 2.826 & $\mathbf{1 5 0 . 7 4}$ & $3.10 \%$ \\
$\mathbf{9}$ & $\mathrm{CO}_{2}$ & 295.15 & 1.066 & $\mathbf{1 6 1 . 9 6}$ & $4.88 \%$ \\
$\mathbf{1 0}$ & $\mathrm{CO}_{2}$ & 295.15 & 1.794 & $\mathbf{1 6 2 . 7 2}$ & $3.77 \%$ \\
$\mathbf{1 1}$ & $\mathrm{CO}_{2}$ & 295.15 & 2.305 & $\mathbf{1 6 4 . 2 2}$ & $3.37 \%$ \\
$\mathbf{1 2}$ & $\mathrm{CO}_{2}$ & 295.15 & 2.608 & $\mathbf{1 6 1 . 3 1}$ & $3.20 \%$ \\
$\mathbf{1 3}$ & $\mathrm{CO}_{2}$ & 295.15 & 2.852 & $\mathbf{1 6 1 . 1 7}$ & $3.21 \%$ \\
$\mathbf{5}$ & $\mathrm{CH}_{4}$ & 292.45 & 4.245 & $\mathbf{3 4 3 3 . 0 0}$ & $15.10 \%$ \\
$\mathbf{8}$ & $\mathrm{CH}_{4}$ & 292.45 & 4.602 & $\mathbf{2 6 2 5 . 3 5}$ & $23.20 \%$ \\
$\mathbf{6}$ & $\mathrm{CH}_{4}$ & 292.45 & 5.002 & $\mathbf{3 8 0 5 . 4 3}$ & $21.10 \%$ \\
$\mathbf{7}$ & $\mathrm{CH}_{4}$ & 292.45 & 5.184 & $\mathbf{3 6 7 1 . 6 0}$ & $24.90 \%$ \\
$\mathbf{9}$ & $\mathrm{CH}_{4}$ & 295.15 & 4.006 & $\mathbf{4 2 6 2 . 7 5}$ & $18.60 \%$ \\
\hline \multicolumn{5}{r}{ Table 5: Henry's constant obtained with biogas and tap water } \\
\end{tabular}

Experimental errors for carbon dioxide henry's constant are sufficiently low. We obtained the same results than with pure water. Methane absorption has decreased with tap water and the separation ratio of methane and carbon dioxide rises to 20 in this experiment. 


\subsection{Results obtained with biogas and recycled water used as solvent in a $\mathrm{CO}_{2}$ absorption process.}

Finally, water used in biogas upgrading process (recirculated water used as solvent for $\mathrm{CO}_{2}$ absorption) has been sampled and tested in the experimental set up. This water was polluted by some sulfur compounds and could contain some carbon dioxide as water regeneration in absorption process is not total. Experimental results are presented in Table 6.

\begin{tabular}{cccccc}
\hline Exp. & Compound & $\mathbf{T}(\mathrm{K})$ & $\begin{array}{c}\text { Partial pressure } \\
\text { (bars) }\end{array}$ & $\begin{array}{c}\text { Henry's } \\
\text { constant }\end{array}$ & $\begin{array}{c}\text { Experimental } \\
\text { error }\end{array}$ \\
\hline $\mathbf{1 4}$ & $\mathrm{CO}_{2}$ & 296.15 & 1.591 & $\mathbf{2 6 6 . 6}$ & $4.84 \%$ \\
$\mathbf{1 5}$ & $\mathrm{CO}_{2}$ & 297.55 & 2.188 & $\mathbf{2 3 2 . 1 8}$ & $4.05 \%$ \\
$\mathbf{1 6}$ & $\mathrm{CO}_{2}$ & 298.65 & 2.585 & $\mathbf{2 1 8 . 5 6}$ & $3.75 \%$ \\
$\mathbf{1 4}$ & $\mathrm{CH}_{4}$ & 296.15 & 4.410 & $\mathbf{4 7 3 0}$ & $20.70 \%$ \\
$\mathbf{1 5}$ & $\mathrm{CH}_{4}$ & 297.55 & 4.482 & $\mathbf{5 8 7 0}$ & $34.80 \%$ \\
\hline \multicolumn{6}{c}{ Table 6: Henry's constant obtained with biogas and recycled process water }
\end{tabular}

This experiment highlights lower dissolution performance of the water after regeneration than pure and tap water. However, the solvent keep good separation ratio of 23 for methane and carbon dioxide which is suitable for such use in biogas upgrading.

\section{Discussion on performances of the system}

A study on experimental errors sensibility indicates that more than $90 \%$ of the uncertainty on Henry's constants is due to the Infra-Red sensor measurement of gas concentration. Combining more accurate measures of gas concentration with this experimental set up will ensure a promising use for more precise characterization.

\section{Conclusion}

We have shown that was missing an easy to use process to determinate Henry's constant of dissolution for gas mix and complex liquids. After this finding, SATUROMETRIX has been designed and built. The adapted equations were also found to calculate the dissolution constant thanks to measured temperature, pressure and gas composition. Three waters were then tested in contact with real biogas mix. Results were obtained with sufficient accuracy to make some conclusion and comparison with literature data. This comparison is presented in table 7. 


\begin{tabular}{|c|c|c|c|c|}
\hline & $\begin{array}{l}\text { Equation of state for one } \\
\text { gas / water [7], [8] }\end{array}$ & $\begin{array}{c}\text { Biogas/pure } \\
\text { water at } \\
292 \mathrm{~K}\end{array}$ & $\begin{array}{c}\text { Biogas/tap } \\
\text { water at } 292 \mathrm{~K}\end{array}$ & $\begin{array}{c}\text { Biogas/recycled } \\
\text { water at } 298 \mathrm{~K}\end{array}$ \\
\hline $\mathrm{H}_{\mathrm{CO}_{2}}(\mathrm{MPa})$ & $\begin{array}{l}142 \text { (à } 292 \mathrm{~K} \text { ) } \\
169 \text { (à } 298 \mathrm{~K})\end{array}$ & $142+/ .8$ & $155^{+} / .8$ & $250 \% .20$ \\
\hline $\mathrm{H}_{\mathrm{CH}_{4}}$ (Mpa) & $\begin{array}{l}3525.4 \text { (à } 292 \mathrm{~K}) \\
3929.8 \text { (à } 298 \mathrm{~K})\end{array}$ & $1500 \% / 200$ & $3500 \% / .800$ & $6000 \%-2000$ \\
\hline $\begin{array}{c}\text { Ratio } \\
\mathrm{H}_{\mathrm{CH}_{4}} / \mathrm{H}_{\mathrm{CO}_{2}}\end{array}$ & $\begin{array}{l}24.8(292 \mathrm{~K}) \\
23.2(298 \mathrm{~K})\end{array}$ & 11.1 & 25.8 & 24 \\
\hline
\end{tabular}

Table 7 : Comparison of obtained Henry's constants with literature data

Results for tap water are in very good agreements with literature data. Methane dissolution is higher in pure water and lower in recycled water. Carbone dioxide dissolution is mainly impacted when recycled water is used. However separation ratio are maintained between tap and recycled water.

\section{Acknowledgements}

This research was supported by the regional funds for innovation and by ADEME (Agence de l'environnement et de la maitrise de l'énergie). All experiments were conducted at the farm of Christophe Canezin, Vic Fezensac, Gers (France). Aria Innovent provided the main operational and material support. LISBP (Ingénierie des Systèmes Biologiques et des Procédés) provided analysis equipment and a scientific support.

\section{Bibliography}

[1] M. Roustan, Tranferts gaz-liquide dans les procédés de traitement des eaux et des effluents gazeux. Tec\&Doc edition, 2003.

[2] R. Sander, Reference database of NIST 69: WebBook of chemistry. National Institute of Standards and Technology, 2001.

[3] B. E. P. Reid R.C. J. M.Prausnitz, The properties of gas and liquids, Fourth edition. Mcgraw-Hill book companie, 1986.

[4] V. Mohebbi, A. Naderifar, R. M. Behbahani, and M. Moshfeghian, "Determination of Henry's law constant of light hydrocarbon gases at low temperatures," J. Chem. Thermodyn., vol. 51, no. 0, pp. 8-11, 2012. 
[5] G. Soave, "20 years of Redlich-Kwong equation of state," Fluid Phase Equilibria, vol. 82, no. 0, pp. 345-359, 1993.

[6] H. Knapp, S. Zeck, and R. Langhorst, "Phase equilibria for the design of gas wash systems: Experimental techniques," Chem. Eng. Process. Process Intensif., vol. 21, no. 1, pp. 25-32, 1987.

[7] Z. Duan and R. Sun, "An improved model calculating $\left\{\mathrm{CO}_{2}\right\}$ solubility in pure water and aqueous $\mathrm{NaCl}$ solutions from 273 to $533 \mathrm{~K}$ and from 0 to 2000 bar," Chem. Geol., vol. 193, no. 3-4, pp. 257-271, 2003.

[8] S. Mao, Z. Duan, D. Zhang, L. Shi, Y. Chen, and J. Li, "Thermodynamic modeling of binary $\mathrm{CH}_{4}-$ H2o fluid inclusions," Geochim. Cosmochim. Acta, vol. 75, no. 20, pp. 5892-5902, 2011.

\section{Appendix A. Nomenclature}

\section{Latin Letters}

$H$ Henry constant $[P a]$

$m$ Sharing coefficient

$M$ Molar mass [g.mol ${ }^{-1}$ ]

$P$ Pressure $[P a]$

$R$ Perfect gas constant

$T$ Temperature $[K]$

$V$ Volume $\left[\mathrm{m}^{3}\right]$

$x$ Liquid molar rate $\left[\mathrm{mol}^{\mathrm{m}} \mathrm{mol}^{-1}\right]$

$y$ Gaseous molar rate $\left[\right.$ mol.mol $\left.^{-1}\right]$

$Z$ Compressibility factor

\section{Greek Letters}

$\rho$ Density $\left[\mathrm{kg} \cdot \mathrm{m}^{-3}\right]$

\section{Subscripts}

$\mathrm{CH}_{4}$ - Related to $\mathrm{CH}_{4}$

$\mathrm{CO}_{2}$ - Related to $\mathrm{CO}_{2}$

$G$ - Related to the gas phase

$i$ - Related to the component $\mathrm{i}$

$L$ - Related to the solvent phase 